\title{
Open borders and cross-border cooperation in regional development
}

\author{
Katarina Hercegová ${ }^{*}$, and Veronika Chernova ${ }^{2,3}$ \\ ${ }^{1}$ Prague Business School, Werichova str. 1145/29, 15200 Prague, Czech Republic \\ ${ }^{2}$ People Friendship University of Russia, Department of International Economic Relations, 6 Miklukho- \\ Maklaya str., Moscow, 117198, Russian Federation \\ ${ }^{3}$ State University of Management, 99 Ryazansky Prospekt, Moscow, 109542, Russian Federation
}

\begin{abstract}
Our paper focuses on the cross-border cooperation in regional development. Specifically, it examines the effect of open borders and international cooperation for the sustainable development of regions. We show that barriers hampering the free movement of capital and labour often lead to worsening the economic and social conditions of border regions and have negative effects on the regional development. Moreover, we provide evidence from recent history and examples of the European Union integration to stress the importance of opening borders and installing the well-functioning cross-border cooperation. In addition, we discuss the effects of the European single currency (as expressed in a classical model of the Open Currency Area) to demonstrate the effects of cross-border trade. Our results can be used by the economic experts and policy-makers who are preoccupied with removing trade barriers and economic sanctions and enhancing the economic prosperity.
\end{abstract}

Keywords: cross-border cooperation, trade flows, barriers, integration processes.

\section{Introduction}

The idea of cross-border cooperation is to cover a region and solve common problems along the region's borders. It is a way of ensuring cooperation and cooperation between different regions and countries within the same region $[1,2]$.

The Initiator Region (IR) is often referred to as the initiate cross-border cooperation within a specific area which has its own rules and regulations for the development of the region $[3,4]$. Cross-border cooperation can also be an opportunity to create a critical mass to agree on common welfare services and solutions and to create an environment for cooperation in the fields of health, education, health and social services to encourage innovation and activity. In addition, the added value can lie in building structures for further cooperation - strengthening cohesion $[5,6]$. This will contribute to the removal of border barriers, to the improvement of living conditions and quality of life for the people of the region and the economy as a whole. It can be seen as an opportunity to inspire cooperation in the fields of health, education, health and social affairs, as well as cross-border

\footnotetext{
* Corresponding author: hercegova@pbs-education.cz
} 
cooperation. It can also be a catalyst for the development of new technologies and services such as biotechnology and biophysics [7].

One way or another, borders may act as barriers or bridges, but the question is whether they can lead to common positive outcomes. It should be noted that by restricting the free movement of people and goods, borders create externalities that lead to controlled, balanced growth $[8,9]$. A porous border may be able to support certain cross-border operations that benefit both sides of the border by replacing walled borders in some regions with porous borders with active and innovative actors.

This paper focuses in particular on the impact of open borders and cross-border cooperation. A good comparison for illustrating the discussion above cam be made for the impact of the European Union (EU) and the United States of America on regional development to understand the relationship between open and closed borders and their impact on economic growth and development $[10,11]$. Institutionalisation of cross-border policies at the EU level offers the opportunity to examine the consequences of European integration from the perspective of borders and regions. The observation of cross-border cooperation in the EU and the United States provides important insights into the impact of such cooperation on regional development, which depends heavily on the degree of cooperation between the two countries in terms of economic growth and development $[12,13]$. With this goal in mind, the following basic arguments can be used. First of all, there are already well-supported results from several case studies in Europe. In addition, we should also note that the history of the EU enlargement is considered limited by the issue of 'European integration', due to its limited ability to establish a strong link between regional integration and economic growth and development in the EU and the United States. European integration in the sense of deepening macro and integration policies, with a focus on cross-border cooperation between the two countries. Therefore, cooperation between the EU and its external borders aims to address issues that cross the borders of individuals and communities, including issues such as migration, economic growth and development, environmental protection and human rights $[14,15]$.

In general terms, the cross-border cooperation also involves using the border situation and the borders to form political coalitions for regional development purposes. Unfortunately, the Euro region is currently ineffective, and despite structural reforms, obstacles remain on the front line of cooperation. It is estimated that removing legal and administrative barriers would allow the European border region to be $8.7 \%$ richer than it is at present [16-18]. This is important when discussing the impact of cross-border cooperation on the economic development of the Euro region. To the best of his knowledge, previous research efforts have not specifically addressed the impact of cross-border cooperation on the economic development of the Eurozone as a whole. Globalisation, and in particular the emergence of Europe as a region, has mitigated the many restrictions on mobility previously imposed by international borders. The European Union's internal borders have been opened physically and symbolically, and cross-border regions have become places of communication and interaction $[19,20]$.

Thence, our understanding of the introduction of state border barriers has put the border region in a rather peripheral and marginal position in terms of mobility and development. Tourism development in the border region was state-centred, characterized by hierarchically organized centralized state institutions, including regional as well as the local administrative districts.

\section{Regional trade and the economic consequences of borders}

New borders that were established in Europe since WWII in 1918 were typically viewed as damaging to a region's economic integration and development, but this does not take into 
account that these new borders followed a pattern of economic fragmentation that emerged in the late nineteenth century $[21,22]$. One can assess the impact of new borders on trade and note that the treatment of the impact of borders is fairly limited. The impact on the new border trade can be estimated in terms of economic growth, employment and economic development, but not in terms of economic integration. We are not in a position to analyse the impact of new borders on economic integration and development after 1914. There is no evidence that boundary changes were systematic, as barriers existed before 1914. Christaller [23], after a study on the effects of borders on urban development in the United States, Germany, and France, observed that border cities could develop limited hinterland areas that disturbed the orderly order of urban hierarchies, in accordance with the well-known central place theory of economic development [24].

This contributed to a broader research effort aimed at untangling the channels through which trade is influenced by countries' borders. Many authors nowadays use a newly created dataset to estimate the impact of border regions on regional economic development in the United States, Germany, and France. Here is where the question emerges: How much would the border effects be reduced if the European Union removed the greatest national distortion in procurement observed and built a truly European transport network? How strongly do local growth factors (for example, population growth, employment as well as the employment growth) influence these results? $[25,26]$ The framework can be built that can examine the new empirical growth economy offers geography. From this perspective, our economic analysis shows that the relationship between productivity growth and trade liberalization is mediated by conditional factors [27].

Our research highlights the role of local factors in the impact of regional trade on productivity and employment growth. In particular, it is important to notice a link between trade liberalisation and productivity growth. In addition to analysing the relationship between trade liberalization and growth productivity, one can propose a framework to complement this literature with studies on the impact of regional trade on productivity and employment growth in the new empirical growth economy. This literature brings together research from the United States, Europe, Asia, Africa and Asia-Pacific, where a wide range of economic and political factors are present, including trade, labour market conditions, economic development, political and social conditions and other factors [28-30].

Moreover, the agglomeration of companies stimulates growth because knowledge emanators are locally limited; hence, the process of cumulative causality in the growth model is strengthened. This aggregation does not affect the equilibrium structure, but individual economic actors are confronted at micro level [31, 32]. For this reason, the researchers attempted to identify the extent to which border friction occurs in places that are confronted with the same price index, in symmetry with the level of the micro-regions [33].

The redrawing of the map affects economic growth, as new nations close off their neighbours, but not as much as the effects of a new border. When countries merge, we gain better access to ideas, customers, and capital, and can therefore anticipate economic benefits, which cab be labelled as the "economies of scale". Some researchers found that when two countries join, they benefit from a limited form of political integration that would allow free movement between them. But allowing a larger size almost always has a positive effect: when a country merges, it gains greater access to ideas, customers, or capital.

\section{Economic consequences of bordering between neighbouring states}

With all the discussion provided above on the economic consequences of bordering and cross-border effect between the neighbouring states, it is important to stress that existing international law does not dictate to states how they should manage their migration flows, 
nor does it dictate how migration policy is formulated [34]. There is a pressing need to protect human rights and to put the individual at the forefront of migration issues and to integrate migration management firmly into the existing international legal framework, which may in some way undermine state sovereignty [35]. It must also be understood that the sovereignty of a state cannot be undermined if it develops a migration management law and a practice that protects the rights of its citizens and the interests of the people of that state. Migration legislation that protects the human rights of migrants can effectively contribute to strengthening state sovereignty by protecting national security and public order. As a result, developing countries in the global North are now protecting themselves against unwanted migration from their neighbours [36]. Developing countries pursue aggressive border security policies aimed at excluding forced migrants from areas where the right to asylum is enshrined. This policy has reached additional territorial regions of sovereign states and has blurred the national borders that this policy seeks to protect. This policy is intended to make access to shelters more difficult and to promote transit zones where asylum seekers are isolated, often in the form of detention centres and detention centres.

This approach to external trade is known as border externalisation and is a complementary strategy aimed at further controlling cross-border movement. It is this action that makes us think about the relationship between the concepts of territory, border and sovereignty. This process of externalizing borders is described in the context of a broader study of territoriality, which suggests how the fluctuating geography of borders redefines our understanding of territoriality and changes longstanding practices of sovereignty [37, 38].

This is being done by many actors on the ground and represented by the United States and Canada, as well as other countries in the region, such as the European Union. The solution seems to depend on a combination of economic and political solutions. Schengen agreement might be under serious attack, and the idea of the EU as a rope of internal borders is at stake, while increasing economic protectionism and international terrorism, as well as growing right-wing populism, are just two examples of the growing euro-centrism in the European Union. The results make it clear that the current political and economic crisis in Europe, especially in Germany and France, is focused mainly on the issue of immigration and border control, not on economic issues.

The globalisation process has changed the previous ones and added a new function to state responsibilities, as responsibility for defending territory and political independence is now linked to guaranteeing security and stability of external borders and protecting national sovereignty and territorial integrity. As a result, forced migration has contributed to an increase in the number of refugees and migrants and the rise of right-wing populism in Europe.

Globalization has transformed existing risks and threats, which are impossible to neutralize if the state focuses only on national security strategies that are limited to national borders. National security has been replaced by human security as a new dimension that integrates people's security and the protection of their rights and freedoms. In a decaying environment, as in the post-war world, it is inevitable to include new strategic factors in the context of human security and security, including human rights, human dignity, freedom of movement and political independence. In order to protect human rights, nation states must behave in accordance with the principles of human dignity, freedom of movement and political independence, and human security.

Of course, citizenship allows states to extend their sovereignty to some extent, but their ability to protect citizens is limited, as imprisoned drug dealers around the world can testify. Borders, for their part, define the limits of their own borders, and only their borders can fully protect themselves. In short, an open border policy might lead to the adverse effects such as an increase in the number of refugees and a reduction in illegal immigration. 


\section{Impact of opening borders and free movement of people}

One of the growing trends among opponents of more migration is a growing trend of economic growth of the region. Here might be the myths surrounding open borders and the impact of free movement on the economies of the European border regions [39]. European Union is partly based on the belief that migrants contribute to wage cuts and rising unemployment.

However, research from many European countries has shown that immigration leads to wages in low-skilled jobs rising, not falling, as we tend to believe. Free movement agreements allow workers to move from countries where jobs are scarce to others where there are many, where labour is scarce or where work is scarce [40]. Southern European countries most affected by the eurozone crisis have moved north in recent years in search of work, according to a European Commission study. The OECD estimates that free movement has brought the average unemployment rate in Europe down to 6\%, and it is difficult to see how admitting more people into a country would not increase its prosperity, leading to an increase in the number of jobs for its citizens and a fall in unemployment [41]. However, with $12 \%$ of the EU population expected to move north in the next few years, migrants will increasingly benefit, leading to a skills and labour shortage that will weigh on economic growth in the EU [42].

Taking all that into consideration, one can see that the Malthusian worldview is ultimately flawed, even dangerous, but it is flawed in the best sense of the word. One can set out the theoretical arguments for open borders, provide empirical evidence showing that immigration is a blessing, and address the economic and social costs and benefits of opening borders. In reality, since richer countries do not make more voluntary commitments, "open borders" must be more fully integrated into the development debate. For most advocates, this does not mean that someone should be allowed into a country without questions. It can be noted that rich countries, faced with a strong moral case for global redistribution, have only two options. Ideally, substantial amounts of foreign aid should be provided to the poor, and if that fails, we must alternatively be prepared to accept a significant number of immigrants from poor countries. Depending on the region, open borders can also mean that countries of origin can also accept a growing number of lifestyle immigrants from rich nations who can contribute to the economies of poorer nations. This equality is reinforced by the fact that workers could move freely, and developing countries may enjoy a higher degree of freedom of movement than their richer counterparts. Equally important for the countries of origin is the continuing threat that they will remain a source of emigration, especially irregular ones, even though economic, political and social conditions have improved considerably. This has been spurred on by the development and partnership programmes in which target countries have invested heavily in development partnerships and programmes, as well as in expanding trade and investment. One can speculate that, as circular migration and transnationalism are increasingly feature of current immigration flows, immigration flows tend to circulate between countries of origin and destination, with many immigrants choosing to spend a period in each of them to create transnational nationalities and communities. Opening up borders is likely to reinforce this trend, and with fewer restrictions on freedom of movement, there will be more freedom of movement within the borders of countries such as the United States and Canada. The outbound movement is also likely to continue, as countries considered "abandoned" by the United States, Canada, Australia, New Zealand, and others have generally lifted their borders. Equally important, there has been a tendency to limit the outflow of migrants to the sending countries, and there have been attempts to escape this restriction, which has led to a significant increase in the number of refugees and asylum seekers in countries such as the United States as well as the members of the Commonwealth represented by the Canada, Australia or the New Zealand. Open borders for goods and free 
trade allow physical resources to flow across the border, which in turn increases their operational capability. Likewise, open borders and labour immigration allow for the creation of new jobs in the form of skilled workers flowing into the wealthier countries such as the United States, Canada, Australia, and New Zealand from poorer countries. One could argue that closed borders are the main policy instrument that maintains the division between rich and poor nations. Keeping the poor apart is an immigration restriction that prevents them from moving to richer countries, though this movement is far more likely than rich countries would think. No one disputes that an open immigration policy would benefit the economic growth of most of the countries around the world. As argued above, open borders and free trade lead to economic development in both labour-abundant and capital-abundant countries where the capital owners would welcome cheaper labour and the labourers would be happier to earn higher wages.

\section{Conclusions}

Overall, role of open borders and cross-border cooperation are very important for the regional economic growth. Therefore, it is hard to underestimate the effects of open borders and crossborder cooperation in regional development.

With regard to the above, efforts should be made worldwide to enhance cross-border cooperation at all levels and to remove obstacles for the international trade and the free movement of people. Even though the traditional fears of international migrants who would take the jobs of the local and ruin the economies never materialize, the development of the new Information and Communication Technologies (ICT) might help to effectively track foreign labourers and keep records of foreign goods. The development of the Internet of Things (IoT) can also contribute to these solutions and help the states to follows the flows of services, goods and people across national borders.

Given all of the above, the recent COVID-19 pandemic which helped to digitalize many sectors of the economy and social life might also make its input into further enhancement of the smart technologies for boosting the cross-border cooperation and regional development. At least, this might present one of the positive effects of the pandemic (perhaps, apart from the reductions of the greenhouse gases as a result of limited overseas travel and massive tourism).

Surely, the world is changing rapidly but the new technologies would surely help us to prioritize and to optimize which might be beneficial for allocating scarce resources and achieving the sustainable economic development for the benefit of all nations worldwide.

Acknowledgments: This study has been supported by the RUDN University Strategic Academic Leadership Program.

\section{References}

1. D. Liberato, E. Alén, P. Liberato, T. Domínguez, European Planning Studies, 26(7), 1347-1365 (2018)

2. T. Yaar-Waisel, Journal of Borderlands Studies, 36(3), 389-404 (2018)

3. J. Van den Broek, P. Benneworth, R. Rutten, Regional Science, 6(1), 55-69 (2019)

4. C. Derichs, Knowledge production, area studies and global cooperation (2017)

5. A. Vulevic, R. Castanho, J. Naranjo Gomez, L. Loures, J. Cabezas, L. Fernández-Pozo, J. Martin Gallardo, Sustainability, 12(5), 1978 (2020) 
6. J. Niño-Amézquita, V. Dubrovsky, A. Jankurová, Czech Journal of Social Sciences, Business and Economics, 6(1), 28-36 (2017)

7. R. Tiganasu, T. Jijie, K. Kourtit, Regional Science Policy \& Practice, 12(5), 867-891 (2020)

8. C. Dumeignil, International Regional Science Review, 0160017621989394 (2021)

9. W. Strielkowski, Y. Tumanyan, S. Kalyugina, Economics and Sociology, 9(2), 293-302 (2016)

10. R. Martin, B. Gardiner, Papers in Regional Science, 98(4), 1801-1832 (2019)

11. D. Burton, Journal of Economic Geography, 19(3), 705-722 (2019)

12. T. Mora, P. Garcia-Duran, M. Millet, Spatial Economic Analysis, 6(3), 271-290 (2011)

13. A. Cieślik, J. Michałek, J. Mycielski Czech Journal of Social Sciences, Business and Economics, 5(2), 6-15 (2016)

14. J. Estevens, Comparative Migration Studies, 6(1), 1-21 (2018)

15. P. Jandová, International Economics Letters, 1(1), 41-48 (2021)

16. R. Camagni, R. Capello, A. Caragliu, Regional Science Policy \& Practice, 11(2), 345366 (2019)

17. M. Grela, A. Majchrowska, T. Michałek, J. Mućk, A. Stążka-Gawrysiak, G. Tchorek, M. Wagner, Is Central and Eastern Europe converging towards the EU-15? (2017)

18. P. Koudelková, W. Strielkowski, D. Hejlová, Danube: Law, Economics and Social Issues Review, 6(1), 25 (2015)

19. M. Van der Woude, Border policing in Europe and beyond: Legal and international issues. In Comparative Policing from a Legal Perspective (2018)

20. G. Popescu, Political Geography, 27(4), 418-438 (2008)

21. N. Wolf, M. Schulze, H. Heinemeyer, The Journal of Economic History, 71(4), 915-949 (2011)

22. A. Schmidt, Politics in Central Europe, 16(s1), 1-22 (2020)

23. M. Karczewicz, Journal of Economics \& Management, 34, 81-102 (2018)

24. K. Basboga, Regional Studies, Regional Science, 7(1), 532-549 (2020)

25. H. Weber, J. Sciubba, European Journal of Population, 35(2), 379-402 (2019)

26. F. Nicoli, A. Reinl, Comparative European Politics, 18(3), 384-419 (2020)

27. D. Kolcava, Q. Nguyen, T. Bernauer, Ecological Economics, 163, 98-112 (2019)

28. P. Shu, C. Steinwender, Innovation Policy and the Economy, 19(1), 39-68 (2019)

29. H. Liao, L. Yang, S. Dai, A. Van Assche, Journal of Asian Economics, 74, 101303 (2021)

30. I. Cabelkova, W. Strielkowski, Society and Economy, 35(4), 513-529 (2013)

31. D. Pumain, R. Reuillon, Urban dynamics and simulation models (2017)

32. M. Nissanke, Structural Change and Economic Dynamics, 48, 103-116 (2019)

33. T. Hardi, A. Uszkai, Sociální Studia, 14(1), 9-30 (2017)

34. D. Carter, H. Goemans, World Politics, 70(1), 1-52 (2018)

35. B. Çall, L. Bianku, I. Motoc (eds.), Migration and the European Convention on Human Rights (2021)

36. E. Ferris, K. Donato, Refugees, migration and global governance: Negotiating the Global Compacts (2019) 
37. M. Deleixhe, D. Duez, Journal of European Integration, 41(7), 921-936 (2019)

38. H. Van Houtum, E. Berg (eds.), Routing borders between territories, discourses and practices $(2018)$

39. M. Gilmartin, P. Wood, Borders, mobility and belonging (2018)

40. D. Dorn, J. Zweimüller, Journal of Economic Perspectives, 35(2), 49-76 (2021)

41. OECD, https://www.oecd.org/newsroom/unemployment-rates-oecd-update-april2021.htm (2021)

42. P. Bite, M. Szombathelyi, L. Vasa, Economics \& Sociology, 13(1), 197-216 (2020) 